\title{
Neighbourhood renewal in Cape Town's inner city: Is it gentrification?
}

\author{
NJ Kotze and IJ van der Merwe
}

\section{OPSOMMING/}

In hierdie navorsing word die stedelike vernuwing wat in die sentrale woonbuurtes van Kaapstad plaasgevind het, ondersoek. Ses woonbuurtes is geïdentifiseer as potensiële gentrifikasie-areas. Data in verband met die woonbuurt en behuisingskenmerke, asook persoonlike en sosiale eienskappe van die inwoners, is verkry met behulp van 'n $10 \%$ sistematiese steekproef. Uit ' $n$ voorlopige ondersoek, waarin die verskillende veranderlikes afsonderlik hanteer is, was dit duidelik dat sommige areas meer met internasionale bevindinge oor gentrifikasie ooreengestem het as ander.

' $n$ Gentrifikasieprofiel is vervolgens vir Kaapstad saamgestel met behulp van diskriminantanalise. Hieruit was dit duidelik dat persoonlike eienskappe soos kwalifikasie, beroep, inkomste en gesinsgrootte, die vernaamste veranderlikes was wat onderskei het tussen persone in hierdie woonbuurtes wat hulle wooneenhede restoreer en dié wat dit nie doen nie. Sosiale eienskappe wat ' $n$ rol gespeel het, was kontak met bure en kollegas, en die ligging van winkels waar klere gekoop word. Veranderlikes wat met die eiendom verband hou en wat 'n belangrike rol gespeel het, was die toestand van die wooneenheid in die verlede en tans, eienaarskap en die aantal slaapkamers.

Met behulp van hierdie veranderlikes was dit moontlik om ' $n$ gentrifikasiemodel vir Kaapstad op te stel waarteen die ses woonbuurtes getoets kon word om te bepaal of die woonbuurtvernuwing wat daar voorkom wel as gentrifikasie geklassifiseer kan word.

\section{- Dr NJ Kotze}

Department of Geography

University of the Orange Free State, Bloemfontein

- Prof IJ van der Merwe

Dean of the Faculty of Arts

University of Stellenbosch, Stellenbosch

\section{INTRODUCTION}

The process of urban renewal, which has occurred in the inner-city neighbourhoods of Cape Town, is examined in this research to ascertain whether this process can be classified as gentrification. Glass (1964:19) first used the term gentrification and it referred to a process observed in London: "..... the working class quarters of London have been invaded by the middle classes - upper and lower. Shabby modest mews and cottages ... have been taken over, when their leases have expired, and have become elegant, expensive residences. Larger Victorian houses, downgraded in an earlier or recent period - which were used as lodging houses or were otherwise in multiple occupation - have been upgraded once again. Once this process of 'gentrification' starts in a district it goes on rapidly until all or most of the original working- class occupiers are displaced and the whole social character of the district is changed."

In the past the bulk of the research on gentrification concentrated on specific aspects of the process, for example changes to the housing stock, the neighbourhoods or the inhabitants of these areas. A striking gap in the research on this urban phenomenon is a failure to capture all the changes that take place in these neighbourhoods. From the literature it is evident that the majority of researchers either theorise on, or use a few variables from census data to explain the process. An apparent lack of fieldwork in residential neighbourhoods that are in transition can also be noticed in the literature.

Bourne (1993) identified two principal definitions of gentrification. The first is restrictive while the second is more inclusive. The first of the definitions describes gentrification as the invasion of working-class neighbourhoods in the inner city by people of the middle class with a higher income, resulting in the replacement or displacement of many of the original occupants. It involves the renovation of dilapidated housing stock to meet the requirements of the new owners. A transformation of class (from working class to middle class) and tenure (from private renting to owner-occupation) as well as a significant price appreciation takes place in these neighbourhoods (Cameron, 1992; Hamnett, 1991; Beauregard, 1986:38). Smith (1987) also stated that the gentrification process not only involves a social change, but also an economic change in the land and housing market. It is this combination of social, physical and economic changes that distinguishes gentrification as an identifiable process or set of processes.

The second definition is more inclusive. It incorporates other forms of neighbourhood change, but without the 
necessity of residential succession or displacement of lower-class households. Studies based on this definition also incorporate upgrading of middle- or upperincome areas. These areas presumably continue to be occupied by the same class, and thus the displacement criterion is either relaxed or ignored (Bourne, 1993).

The choice of definition for this study is that of Bourne (1993) based on the urban change observed in London by Glass in 1964 . This research was motivated by the displacement criterion for the changing and upgrading of older central urban areas.

\section{CAPE TOWN AS STUDY AREA: DATA AND VARIABLES}

The study was conducted (1995) in the residential neighbourhoods within the municipal substructure "Cape" in the Cape Town metropolitan area. The substructure includes residential areas from Rugby in the north, Mitchell's Plain in the southeast and Bakoven in the west. Owing to the size of the study area, only neighbourhoods with the potential of being gentrified were included in the study. To identify residential areas with gentrification potential, the assistance of estate agents and town planners of the municipality of Cape Town was enlisted. With their aid, six residential areas (De Waterkant, Bo-Kaap, Lower Gardens, Woodstock, Salt River and Walmer Estate), within a radius of $4 \mathrm{~km}$ from the central business district (CBD) of Cape Town, were identified as potential gentrification areas (see Figure 1). In De Waterkant, Bo Kaap, Lower Gardens and Walmer Estate the total residential area was included in the research, but in the case of Woodstock and Salt River only the areas south of Victoria Road were included. In these two neighbourhoods urban renewal was only noticeable in the higher lying areas with a view of the CBD and Table Bay.

Neither the data from the 1991 nor the 1996 census could be used, because the boundaries for the census wards did not correspond with those of the residential areas in the study. The data for the study were obtained by means of a $10 \%$ systematic sample questionnaire survey that was conducted in the six residential neighbourhoods. A questionnaire was completed for every tenth housing unit in all the streets within the six neighbourhoods. In cases where the information was denied or contact with the inhabitants of a housing unit could not be established the adjacent unit was used. A total of 293 questionnaires were completed within the study area. The survey obtained data concerning the neighbourhoods and housing characteristics of these areas, as well as the personal and social characteristics of the residents.

\section{HISTORIC DEVELOPMENT AND URBAN RENEWAL IN CAPE TOWN}

Urban decay and renewal should be seen as byproducts of urban growth. The spatial transformation of the urban structure usually takes place in an unbalanced manner. The result is that growth areas will de- velop at the expense of stagnant areas or even areas of decline. These areas of decline are usually problem areas of deterioration and blight that can develop in older urban areas. Factors that will result in urban decay, are social disorganisation, changes to the population structure, lack of maintenance of buildings, competition with other land uses and irrational decision making (Van der Merwe, 1989:137).

During gentrification working-class neighbourhoods in the inner city are invaded by people of the middle class with a higher income, resulting in the replacement or displacement of many of the original occupants. In this study the condition of the neighbourhoods, their housing stock as well as their inhabitants could not be tested in the past. To understand the process of urban renewal in Cape Town, it is necessary to study the development and the downgrading that took place in the city. Until the settlement of Europeans in the Cape, the local population at the southern tip of Africa had no urban tradition (Lemon, 1991:1). Within 10 years of Jan van Riebeeck's arrival in Table Bay in 1652, there were already elements of a town and the population grew to 394 (Cook, 1991:26), and because of this the Europeans, with their urban tradition, saw urban areas as their cultural domain (Lemon, 1991:1).

The settlement in Table Bay grew rapidly and during the 1806 British census it was found that $21 \%$ of the Cape Colony's population was living in Cape Town and only $39 \%$ of them were of European descent. The urban character of Cape Town was already well established by 1855 with 3891 houses and shops and a population of 25189 (Cook, 1991:27). Metropolitan development in Cape Town started in 1861 when railway lines to Wynberg and later to Muizenberg were built and Bellville was developed next to the main line to the interior (Cook, 1991:27). Owing to the improved transport system, wealthier people started to leave District Six (presently known as Zonnebloem) and resettled in Green Point and Sea Point. Because of the resettlement of these wealthy people, neighbourhood decay started in this older residential area between 1860 and 1870 (Hart, 1988).

Because of the dilapidated state of District Six and other older neighbourhoods in Cape Town, these areas became home to people of different race groups. With the outbreak of bubonic plague in Cape Town during 1902, all black inhabitants of the city were relocated to the N'dabeni township (Swanson, 1977). The process of decay in other old neighbourhoods of the city, for example De Waterkant that developed between 1793 and 1894, only started during the twentieth century (Historiese De Waterkant verloor sy karakter nou vinnig, 1992).

The urban renewal process in Cape Town started in 1966 after the inclusion of District Six as a White residential area under the Group Areas Act (Hart, 1988). Until 1978 a total of 33446 official Coloured people, as well as an estimated 5000 unlawful tenants were removed from this area, and most of the housing units of the neighbourhood were demolished (Cook, 1991:32). In De Waterkant the renewal process started in 1968 


\section{FIGURE 1: INNER CITY NEIGHBOURHOODS OF CAPE TOWN}

when 35 Loader Street was purchased and renovated by a Mr. Austen (Historiese De Waterkant verloor sy karakter nou vinnig, 1992). Neighbourhood renewal in Woodstock started in the late 1980s with the recommendation by the President's Council that municipalities must have the right to decide on the race composition of neighbourhoods under their jurisdiction. Many people saw this as the beginning of the abolishment of the Group Areas Act. More wealthy Coloured people started to settle in Lower Woodstock, and this process also repeated itself in Upper Woodstock where white people from the working class were replaced by more wealthy people (Garside, 1993).

Although there are strong indications that the properties in the inner-city neighbourhoods were in a dilapidated state during the 1950s and 1960s and that urban renewal was taking place, this process should be investigated to ascertain whether the renewal can be classified as gentrification.

\section{ESTABLISHING WHETHER URBAN RENEWAL IN CAPE TOWN IS GENTRIFICATION}

The six residential areas included in the study have the following characteristics in common: All these neighbourhoods are located within a radius of $4 \mathrm{~km}$ from the CBD of Cape Town (see Table 1). The two oldest areas are the Bo-Kaap and De Waterkant with an average property age of 124 and 112 years respectively. In a South African context they are rated as old neighbourhoods. A large number of medium-density housing units are to be found in these areas, ranging from $45 \%$ in Walmer Estate to $88 \%$ in De Waterkant. In only two of the neighbourhoods, Lower Gardens (78\%) and De Waterkant $(77 \%)$ the majority of the properties have been renovated, and the highest percentage of owneroccupiers is to be found in Walmer Estate (72\%) and Salt River (68\%). In all of these residential areas the local government was in the process of upgrading and 
TABLE 1: $\quad$ POTENTIAL GENTRIFICATION AREAS (1995)

\begin{tabular}{|l|c|c|c|c|c|}
\hline Neighbourhoods & $\begin{array}{c}\text { Distance from } \\
\text { the CBD }\end{array}$ & $\begin{array}{c}\text { Age of neigh- } \\
\text { bourhood }\end{array}$ & $\begin{array}{c}\text { \% of medium- } \\
\text { density housing }\end{array}$ & $\begin{array}{c}\text { \% of owner } \\
\text { occupiers }\end{array}$ & $\begin{array}{c}\text { \% of properties } \\
\text { renovated }\end{array}$ \\
\hline Bo-Kaap & 0,9 & 124 years & 87,8 & 68,4 & 34,2 \\
\hline De Waterkant & 1 & 112 years & 88 & 44,4 & 76,5 \\
\hline Lower Gardens & 1 & 110 years & 73,8 & 47,1 & 77,8 \\
\hline Woodstock & 2,6 & 90 years & 76,8 & 67,0 & 31,9 \\
\hline Salt River & 3,2 & 83 years & 68,3 & 68,4 & 21,1 \\
\hline Walmer Estate & 2,7 & 69 years & 45 & 72,0 & 34,6 \\
\hline
\end{tabular}

TABLE 2: $\quad$ DISCRIMINANT AND CLASSIFICATION FUNCTIONS OBTAINED AFTER STEPWISE DISCRIMINANT ANALYSIS

\begin{tabular}{|c|c|c|c|}
\hline \multirow[t]{3}{*}{ Variables } & \multicolumn{3}{|c|}{ Function coefficients } \\
\hline & \multirow{2}{*}{$\begin{array}{c}\text { Canonical Discriminant } \\
\text { (standardise) }\end{array}$} & \multicolumn{2}{|c|}{ Classification } \\
\hline & & Restorers & Non-restorers \\
\hline Occupation & 0,7016 & 0,9004 & 1,7663 \\
\hline Family size & 0,4989 & 0,5112 & 1,0775 \\
\hline Condition of property in the past & $-0,4899$ & 4,3414 & 3,0834 \\
\hline Qualifications & $-0,3187$ & 4,9516 & 4,3930 \\
\hline Condition of property at present & 0,2845 & 1,4776 & 2,4139 \\
\hline Purchasing of clothes & $-0,1738$ & 6,9169 & 6,3066 \\
\hline Ownership & 0,1693 & 0,9563 & 1,3172 \\
\hline Contact with colleagues & $-0,1355$ & 19,6720 & 18,9109 \\
\hline Number of bedrooms & 0,1248 & 2,4121 & 2,6908 \\
\hline Income & 0,1020 & 2,6254 & 2,8053 \\
\hline Contact with neighbours & $-0,0916$ & 2,2794 & 2,0662 \\
\hline $\begin{array}{l}\text { Gender } \\
\text { Marital status } \\
\text { Language } \\
\text { Age of respondents } \\
\text { Type of housing unit } \\
\text { Number of rooms } \\
\text { Church attendance } \\
\text { Sport participation } \\
\text { Purchasing of groceries } \\
\text { Location of bank }\end{array}$ & \multicolumn{3}{|c|}{ No important distinguishing variables } \\
\hline
\end{tabular}

beautifying (planting trees, developing parking areas) the neighbourhood at the time of the study (1995)

When the housing units in the six neighbourhoods were scrutinised, it was evident that a large percentage had the same basic floor plan, although they were built in different eras resulting in different façades (see Figure 2). The diagram represents no specific housing unit found in these areas and is a schematic representation of the floor plans to be found in these neighbourhoods as observed during the gathering of data. The bathroom at the back of the housing unit was a later addition to these properties. The reason for this type of floor plan must have been a shortage of land close to the $\mathrm{CBD}$, with the result that row houses were developed for the working class in these inner-city neighbourhoods of Cape Town.
From the initial investigation of the data collected during the systematic sample survey, in which the different variables were considered separately, there were indications that the urban renewal process evident in some of the neighbourhoods corresponded more closely to international findings on gentrification than in other areas.

\section{Discriminant analysis}

To test whether the urban renewal that was evident in the six residential areas (De Waterkant, Bo-Kaap, Lower Gardens, Woodstock, Salt River and Walmer Estate) was in fact gentrification, a discriminant analysis procedure was undertaken. This is a multivariate statistical technique that is used to distinguish between two or more opposing groups with the aid of a number of relevant variables (Klecka, 1980:7). In this case study it was 


\section{FIGURE 2:}

HOUSING UNITS IN STUDY AREA

used to distinguish between people who had renovated and those who had not renovated their housing units. The success rate of the procedure depends on the availability of a set of distinguishable variables that can be measured at interval or ratio level (Klecka, 1980:8). The value of this technique lies in the fact that it has the ability to use all the variables simultaneously to determine which ones contributed to the ability to distinguish between the different groups investigated, and to what extent each of them does so. Discriminant analysis does not only make it possible to distinguish between two or more groups, but also to predict to which group each case belongs (SPSS/PC+, 1986).

In this technique the measuring scale of the variables is very important, because it influences the effectiveness of the procedure. Van Deventer and Van der Merwe (1987) found that if too many of the variables are coded on a nominal scale, it will lead to sub-optimal distinguishing potential. However, some variables in this study could only be coded on a nominal scale, and have to be used as such. A further assumption is that each group is drawn from a population which has a multivariate normal distribution. Such a distribution exists when each variable has a normal distribution about fixed values on all others (Blalock, 1979:452). This permits the precise computation of tests of significance and probabilities of group membership. When this assumption is violated, the computed probabilities are not exact, but they may still be quite useful if interpreted with caution (Lachenbruch, 1975:44).

In this study 21 variables were analysed by means of the discriminant procedure of SPSS/PC+, and Rao's $V$ was used as a selection criterion. Eleven variables were selected by the technique as being of significant value in discriminating between people who renovated their properties and those who did not. Personal characteristics such as occupation, family size, qualifications and income were some of the important variables (see Table 2). The social characteristics selected as the most important were where the inhabitants purchased their clothes, and contact with colleagues and neighbours. Property characteristics such as the condition of the property in the past, condition of the property now, ownership and number of bedrooms were also important variables. These results held no surprises, because these variables cor- 
TABLE 3: $\quad$ RECLASSIFICATION RESULTS OF GROUPS AS PREDICTED BY DISCRIMINANT ANALYSIS

\begin{tabular}{|c|c|c|c|}
\hline \multirow[t]{2}{*}{ Groups } & \multirow[t]{2}{*}{ Number of cases } & \multicolumn{2}{|c|}{ Predicted group affiliation } \\
\hline & & Restorer & Non-restorer \\
\hline Restorer & 111 & $\begin{array}{c}93 \\
(83,8 \%)\end{array}$ & $\begin{array}{c}18 \\
(16,2 \%)\end{array}$ \\
\hline Non-restorer & 182 & $\begin{array}{c}29 \\
(15,9 \%)\end{array}$ & $\begin{array}{c}153 \\
(84,1 \%)\end{array}$ \\
\hline
\end{tabular}

\section{TABLE 4: $\quad$ GENTRIFICATION PROFILE FOR CAPE TOWN}

\begin{tabular}{|c|c|}
\hline Variables & Gentrification characteristics \\
\hline \multicolumn{2}{|l|}{ Personal characteristics } \\
\hline $\begin{array}{l}\text { Qualification } \\
\text { Occupation } \\
\text { Income } \\
\text { Family size }\end{array}$ & $\begin{array}{l}\text { Post-matric qualification } \\
\text { White-collar job } \\
\text { Higher than R60 } 000 \text { p.a. } \\
\text { 2,9 persons }\end{array}$ \\
\hline \multicolumn{2}{|l|}{ Behaviour characteristics } \\
\hline $\begin{array}{l}\text { Contact with neighbours } \\
\text { Contact with colleagues } \\
\text { Purchasing of clothing }\end{array}$ & $\begin{array}{l}\text { No contact with neighbours } \\
\text { Contact with colleagues } \\
\text { CBD and other areas of city }\end{array}$ \\
\hline \multicolumn{2}{|l|}{ Property characteristics } \\
\hline $\begin{array}{l}\text { Condition in the past } \\
\text { Condition now } \\
\text { Ownership } \\
\text { Number of bedrooms }\end{array}$ & $\begin{array}{l}\text { Dilapidated condition } \\
\text { Renovated condition } \\
\text { Owner occupier } \\
\text { 2,6 bedrooms }\end{array}$ \\
\hline
\end{tabular}

responded with international gentrification research findings (Lees 1994; Filion 1991; Gale 1979; Lang 1981:18).

The success of the discriminant analysis in distinguishing between restorers and non-restorers is indicated in the re-classification results of the procedure. Of the 293 cases used in the research, 246 were classified correctly, translating into a success rate of $84 \%$ (see Table $3)$. By using these 11 variables as chosen by discriminant analysis, a prediction as to whether a person with certain characteristics would restore his property and hence could be classified as a gentrifier in Cape Town could be made with relative certainty.

\section{Gentrification profile for Cape Town}

The result of the discriminant analysis only gave a general indication of the characteristics of restorers and non-restorers - for example, that the first-mentioned group had smaller families, higher qualifications, whitecollar jobs, etc., while the last group displayed the opposite characteristics. The 11 variables were then used to compile a gentrification profile for Cape Town, but in order to use these variables in an explanatory framework, more exact quantification was needed. To create the profile for Cape Town, the averages were calculated for variables with interval data. For those with nominal data, contingency tables were constructed and the per- centages of respondents that did restore their properties were used as guideline for the profile.

This manipulation of the data was used to construct a profile of a restorer or potential gentrifier for Cape Town. The personal characteristics of a person who does restore his/her housing unit are as follows: he/she will have a family size of 2,9 persons, a postmatric educational qualification, a white-collar job and an income higher than R60 000 per year. The behavioural characteristics of these people are that they have no contact with their neighbours, but do have contact with their colleagues. They purchase their clothing in the CBD and other areas of the city. The characteristics of the property is that the housing unit was in a dilapidated condition in the past, but has been renovated, is owneroccupied and has an average of 2,6 bedrooms (see Table 4).

These characteristics or gentrification profile for Cape Town was subsequently used to determine whether the renewal process that is taking place in the city is actually gentrification.

\section{Gentrified areas in Cape Town}

A neighbourhood profile was developed for each of the six inner-city areas of Cape Town that were included in the study. The six neighbourhood profiles 
were tested against the gentrification profile of Cape Town to ascertain whether they had the same characteristics and whether the renewal process in each of them could therefore be classified as gentrification. It was found that the inhabitants and housing units of

TABLE 5: CORRESPONDENCE BETWEEN GENTRIFICATION PROFILE AND THE RESTORATION PER NEIGHBOURHOOD

\begin{tabular}{|l|c|c|}
\hline & $\begin{array}{c}\text { \% correspon- } \\
\text { dence with gen- } \\
\text { trification profile }\end{array}$ & $\begin{array}{c}\text { \% of restorers per } \\
\text { neighbourhood }\end{array}$ \\
\hline De Waterkant & 72,7 & 76,5 \\
Lower Gardens & 72,7 & 77,8 \\
Warmer Estate & 45,5 & 34,6 \\
Woodstock & 36,4 & 30,6 \\
Bo-Kaap & 36,4 & 34,2 \\
Salt River & 27,2 & 21,1 \\
\hline
\end{tabular}

two of the neighbourhoods, De Waterkant and Lower Gardens, exhibited a $73 \%$ correspondence with the gentrification profile (see Table 5). In both these neighbourhoods the same three variables did not correspond with the gentrification profile. The respondents in these areas had more contact with their neighbours. Secondly, the condition of their properties had been better in the past and finally, fewer of the properties were occupied by their owners. The higher contact rate with neighbours could be the result of a more homogeneous socio-economic population in these two areas, as people with white-collar jobs, higher qualifications and incomes have resettled here and have totally displaced the original inhabitants. A reason for the better condition of the properties in the past could be that, according to the respondents, the older housing units in De Waterkant and Lower Gardens need to be renovated constantly or otherwise they become dilapidated again. In both these areas the renewal process had almost been

FIGURE 3: $\quad$ GENTRIFICATION PROFILE IN CAPE TOWN 
completed, probably tenants were occupying properties that had been renovated by gentrifiers that had already left the area. Finally the two neighbourhoods were the smallest in the case study and represented only $12 \%$ of the cases in the research; because of this, it had a smaller influence on the outcome and construction of the gentrification profile with the discriminant analysis. Although these two residential areas do not correspond wholly with the gentrification profile, the urban renewal process in these neighbourhoods has to be regarded as gentrification.

In the other four neighbourhoods, Walmer Estate (46 $\%)$, Woodstock (36 \%), Bo-Kaap (36 \%) and Salt River $(27 \%)$ fewer characteristics corresponded with the gentrification model of Cape Town and therefore the renewal process cannot be classified as gentrification at this stage. With the exception of the Bo-Kaap, the other three neighbourhoods were farther away from the CBD than De Waterkant and Lower Gardens (see Figure 3). In time, if more middle-class people were to move into these four neighbourhoods, the composition of the areas could possibly change to such an extent that one would be able to classify them as gentrified neighbourhoods.

\section{CONCLUSION}

This paper examined urban renewal in Cape Town and tried to ascertain whether these changes could be classified as gentrification. With the aid of discriminant analysis a gentrification profile was constructed for the city. The characteristics of Cape Town's gentrifiers held no surprises, because the same variables were identified as important in other cities of the world. The inhabitants and housing stock of the six neighbourhoods were tested against the gentrification profile to ascertain whether the renewal could be classified as gentrification.

Not even those neighbourhoods where the renewal process was almost completed, corresponded completely with the gentrification profile that was developed for Cape Town, but the variables that caused the discrepancy could be explained logically. In time even those neighbourhoods that had little in common with the gentrification profile could change to such an extent that their inhabitants and housing stock would correspond more closely to the gentrification of Cape Town. This can only happen if more of the original inhabitants in these inner-city neighbourhoods of Cape Town are displaced by people of higher socio-economic status.

In most cities of the world urban change and renewal are established processes, and it is also known who is doing the upgrading and where gentrification is taking place in Cape Town. But a question that remains unan- swered is: what happens to people in Cape Town as well as other cities of the world who are displaced by gentrification?

\section{REFERENCES}

BOURNE, LS. 1993. The demise of gentrification? A commentary and prospective view. Urban Geography 14(1):95-107. BEAUREGARD, RA. 1986. The chaos complexity of gentrification. In Smith, N. \& Williams, P. (Eds). Gentrification of the City. Boston. Allen \& Unwin.

BLALOCK, HM. 1979. Social Statistics. New York. McGrawHill.

CAMERON, S. 1992. Housing, gentrification and urban regeneration policies. Urban Studies 29(1):3-14.

COOK, GP. 1991. Cape Town. In Lemon, A. (Ed.). Homes Apart: South Africa's Segregated Cities. Cape Town. David Philip.

Historiese De Waterkant verloor sy karakter nou vinnig. 1992. Die Burger, 3 Oktober.

FILION, P. 1991. The gentrification - social structure dialectic: A Toronto case study. International Journal of Urban and Regional Research 15(4):553-236.

GALE, DE. 1979. Middle class resettlement in older urban neighbourhoods. Journal of the American Planning Association 45:293-304.

GARSIDE, J. 1993. Inner city gentrification in South Africa: the case of Woodstock, Cape Town. GeoJournal 30:29-35.

GLASS, R. 1964. Aspects of change. In Centre for Urban Studies (Ed). London: Aspects of Change. London: MacGibbon \& Kee.

HART, DM. 1988. Political manipulation of urban space: the razing of District Six, Cape Town. Urban Geography 9:603-628.

HAMNETT, C. 1991. The blind men and the elephant: the explanation of gentrification. Transactions, Institute of British Geographers (New Series) 16:173-189.

KLECKA, WR. 1980. Discriminant Analysis. Beverly Hills. Sage.

LACHENBRUCH, PA. 1975. Discriminant Analysis. New York. Hafner.

LANG, MH. 1982. Gentrification amid urban decline. Cambridge. Balinger.

LEMON, A. 1991. The Apartheid City. In Lemon, A. (Ed.): Homes Apart: South Africa's Segregated City. Cape Town. David Philip.

LEES, L. 1994. Gentrification in London and New York: an Atlantic gap? Housing Studies 9(2):199-217.

SMITH, N. 1979. Toward a theory of gentrification: a back to the city movement by capital, not people. Journal of the American Planners Association 45:538-548.

SMITH, N. 1982. Gentrification and uneven development. Economic Geography 58:139-155.

SMITH, N. 1987. Gentrification and the rent gap. Annals of the Association of American Geographers 77:462-478.

SWANSON, MW. 1977. The sanitation syndrome: bubonic plague and urban native policy in the Cape Colony, 1900-1909. Journal of African History 18(3):387-470.

VAN DER MERWE, IJ. 1989. Die stad en sy omgewing. Stellenbosh. Universiteit-Uitgewers en Boekhandel.

VAN DEVENTER, $W$ \& VAN DER MERWE, IJ. 1987. ' $n$ Ruimtelike en sosio-ekonomiese profiel van die ekonomiese aktiewe vrou in Kaapstad. S.A. Geograaf 14:65-72. 